\section{Biologia molecular do câncer cervical}

\section{Molecular biology of cervical cancer}

\author{
Waldemar Augusto Rivoire1,2 \\ Helena Von Eye Corleta1-3 \\ Ilma Simoni Brum4 \\ Edison Capp 1,2,4
}

\author{
'Departamento de Ginecologia e Obstetrícia. Faculdade de \\ Medicina. Universidade Federal do Rio Grande do Sul. Rua Dr. \\ Barros Cassal, 411/22. Porto Alegre, RS, Brasil. CEP: 90.035-003. \\ E-mail: edcapp@ufrgs.br \\ 2Serviço de Ginecologia e Obstetrícia. Hospital de Clínicas de \\ Porto Alegre. Porto Alegre, RS, Brasil. \\ ${ }^{3}$ Gerar - Núcleo de Reprodução Humana do Hospital Moinhos de \\ Vento. Porto Alegre, RS, Brasil. \\ ${ }^{4}$ Departamento de Fisiologia. Instituto de Ciências Básicas da \\ Saúde. Universidade Federal do Rio Grande do Sul. Porto Alegre, \\ RS, Brasil.
}

\section{Resumo}

A carcinogênese é um processo de múltiplas etapas. Alterações no equilíbrio citogenético ocorrem na transformação do epitélio normal a câncer cervical. Numerosos estudos apoiam a hipótese de que a infecção por HPV está associada com o desenvolvimento de alterações malignas e pré-malignas do trato genital inferior. Neste trabalho são apresentadas as bases para a compreensão da oncogênese cervical. O ciclo celular é controlado por proto-oncogenes e genes supressores. Quando ocorrem mutações, proto-oncogenes tornam-se oncogenes, que são carcinogênicos e causam multiplicação celular excessiva. A perda da ação de genes supressores funcionais pode levar a célula ao crescimento inadequado. O ciclo celular também pode ser alterado pela ação de vírus, entre eles o HPV (Human Papiloma Virus), de especial interesse na oncogênese cervical. Os tipos de HPV 16 e 18 são os de maior interesse, freqüentemente associados a câncer cervical $e$ anal. O conhecimento das bases moleculares que estão envolvidas na oncogênese cervical tem sido possível devido a utilização de técnicas avançadas de biologia molecular. A associação destas técnicas aos métodos diagnósticos clássicos, poderão levar a uma melhor avaliação das neoplasias cervicais e auxiliar no desenvolvimento de novas terapias, talvez menos invasivas $e$ mais efetivas.

Palavras-chave Biologia molecular, Carcinoma cervical uterino, Papiloma vírus humano 


\section{Introdução}

Existe forte evidência clínica e experimental de que o papiloma vírus humano (HPV) tem papel central no desenvolvimento e crescimento do câncer cervical. Contudo, é sabido que a carcinogênese é um processo de múltiplas etapas. Alterações no equilíbrio citogenético ocorrem no momento da transformação do epitélio cervical normal em câncer. Numerosos estudos apoiam a hipótese de que a infecção por HPV está associada ao desenvolvimento de alterações malignas e pré-malignas do trato genital inferior. ${ }^{1,2}$ Neste trabalho são apresentadas as bases biomoleculares para a compreensão da oncogênese cervical.

\section{Proto-oncogenes e genes supressores}

Os genes são compostos por moléculas de DNA, no núcleo celular. Eles especificam seqüências de aminoácidos que devem ser ligados uns aos outros para formar determinada proteína, que deverá realizar o efeito biológico do gene. Quando um gene é ativado, a célula responde sintetizando a proteína codificada. Mutações em um gene podem perturbar a célula, alterando a quantidade de proteína ou a atividade desta.3-5

Duas classes de genes, pequenas em relação ao total de genes, têm papel chave no desenvolvimento do câncer. Em suas configurações normais, elas dirigem o ciclo celular em uma intrincada seqüência de eventos, pelos quais as células crescem e se dividem. Proto-oncogenes estimulam, enquanto genes supressores inibem os processos de divisão celular. Coletivamente, essas duas classes de genes são responsáveis pela proliferação descontrolada, encontrada nos cânceres em humanos. 6,7

Quando ocorrem mutações, proto-oncogenes tornam-se oncogenes, que são carcinogênicos e causam multiplicação celular excessiva. Essas mutações levam o proto-oncogene a expressar em excesso sua proteína estimuladora do crescimento ou a produzir uma forma mais ativa. Os genes supressores de tumores, em contraste, contribuem para o desenvolvimento de câncer quando são inativados por mutações. O resultado é a perda da ação de genes supressores funcionais, o que priva a célula de controles cruciais para a inibição de crescimento inapropriado.

\section{Ciclo celular e oncogenes}

O ciclo celular é composto por quatro estágios. $\mathrm{Na}$ fase G1 (gap 1 = interfase), a célula aumenta de tamanho e prepara-se para copiar seu DNA. A cópia (replicação) ocorre na fase seguinte, chamada de $\mathrm{S}$ (síntese), e permite que a célula duplique precisamente seus cromossomos. Depois de replicados os cromossomos, inicia a fase G2 (gap 2), durante a qual a célula prepara-se para a fase $\mathbf{M}$ (mitose) - fase na qual a célula-mãe, aumentada, finalmente se divide ao meio, para produzir duas células-filhas, com igual número de cromossomos. As célulasfilhas imediatamente entram em fase G1 e podem reiniciar o ciclo celular. Alternativa, também, é parar o ciclo temporária ou definitivamente 3,5 (Figura 1). A fase $\mathrm{G} 1$ possui um ponto de checagem, G1/S, controlado pela via do $\mathrm{pRb}$ (proteína do retinoblastoma). Uma vez que a célula passe este ponto, ela é compelida a replicar seu DNA. Caso ocorra cópia incorreta do DNA durante S ou lesão do DNA, a célula não passará o ponto de checagem G2/M, e ocorrerá parada de crescimento e apoptose (senescência e morte programada) induzidos pelo gene $p 53.8$

\section{Figura 1}

Ciclo celular.

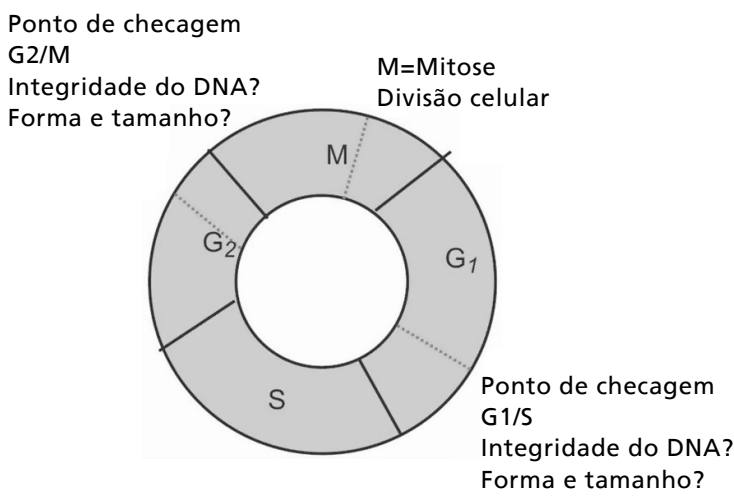

Fontes: Alberts et $a / 3$ e Stanley. ${ }^{8}$

Várias proteínas inibidoras podem parar o avanço deste ciclo. Entre elas $p 15$ e $p 16$, que atuam bloqueando componentes essenciais para progressão do ciclo celular, como CDK (cyclin-dependent kinases) e ciclinas, impedindo o avanço do ciclo da fase G1 para S. Outros inibidores são $p 21$, associado 
ao proto-oncogene ras, e $p 53$, que monitoram a saúde celular, a integridade de seus cromossomos e a execução correta das diferentes fases do ciclo.

As células humanas estão equipadas com mecanismos de controle da divisão celular. Mutações no conteúdo genético destas células podem superar estas defesas e contribuir para a formação do câncer. Um desses mecanismos de ação é a apoptose, que ocorre quando componentes essenciais estão lesados ou o controle do sistema desregulado. O desenvolvimento de células tumorais implica em escape a esse mecanismo. A proteína $p 53$, entre as suas várias funções, auxilia o início da apoptose; sua inativação, por mutação, reduz a chance de células geneticamente danificadas serem eliminadas, iniciando um processo carcinogênico. Outro mecanismo de controle da divisão celular limita o número de vezes que determinada célula se reproduz. Nesse mecanismo, as pontas dos cromossomos (telômeros) marcam o número de divisões, e no momento apropriado iniciam senescência e morte, por ocasião da telomerase. A ativação desta enzima induz à imortalização celular, evento indispensável para a carcinogênese.

\section{Papiloma vírus humano}

Os vírus do papiloma humano (HPV) são membros da família papovaviridae. HPV formam uma família de mais de 130 genótipos, podendo ser divididos em tipos cutâneos ou de mucosa.9,10 O genoma destes vírus consiste de 8-9 janelas de leitura (open reading frames) e de uma região regulatória. Os genes virais são chamados de precoces (early, E) ou tardios (late, L) dependendo de quando são expressos. A expressão das proteínas virais é fortemente regulada e dependente da diferenciação celular. ${ }^{11}$ HPV de mucosa são divididos nos tipos de risco "alto", "intermediário" e "baixo" dependendo da lesão com a qual estão associados. Tipos de alto-risco são predominantemente associados ao câncer cervical, enquanto que os tipos de baixo risco são comumente detectados em verrugas genitais.

\section{Biologia molecular do câncer cervical}

Estudos epidemiológicos das lesões cervicais uterinas, nos últimos 20 anos, sugeriram a participação de agentes carcinogênicos venéreos (sêmen, vírus de Epstein-Barr, citomegalovírus, herpes simples tipo II). O HPV surgiu como principal suspeito ao ser encontrado em cerca de $90 \%$ dos cânceres cervicais e por possuir oncogenes (E6 e E7) com potencial de transformação. $5,10,12-14$ O mecanismo pelo qual os tipos de HPV transformam as células ainda não é completamente compreendido. A seqüência de eventos representada na Figura 2 é geralmente aceita. ${ }^{8}$ A maioria dos trabalhos foi realizada com os dois subtipos mais freqüentemente encontrados: HPV16 e HPV18. É possível, contudo, que diferentes mecanismos sejam utilizados pelos diferentes subtipos para induzir transformação neoplásica. Em particular, há evidências de que o HPV33 transforme as células por outra via. ${ }^{15}$

Figura 2

Replicação do papiloma vírus nas células cervicais.

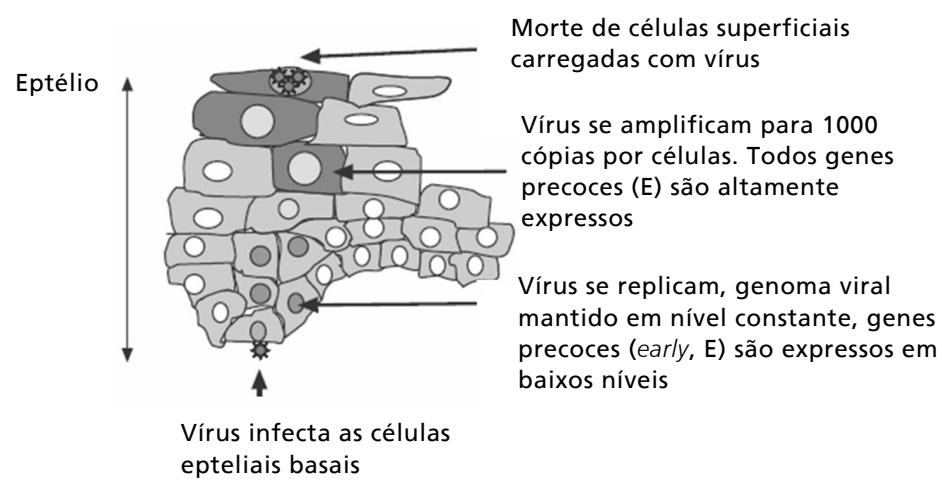

Fontes: Stanley 8 e Stubenrauch et al.14

Nota: Os vírus 6 e 11, na maioria das vezes provocam somente infecção, tendo como resultado a morte celular. Os vírus 16 e 18, ao invés de levarem a morte celular, induzem a sua imortalização, oportunizando o processo oncogênico.

Todos os tipos de HPV são replicados exclusivamente no núcleo da célula hospedeira. Em lesões de pele benignas, associadas ao HPV, o genoma viral encontra-se separado do DNA celular e surge como um plasmídio extra-cromossômico (corpo epissomal). Em lesões malignas associadas aos HPV 16 e 18, contudo, o DNA viral se integra aos cromossomos hospedeiros. 16,17 Para integrar-se ao DNA celular, é necessário que haja uma quebra no genoma viral. Esta separação não ocorre de forma aleatória, pois a maioria ocorre nas regiões $E 1$ e E2 do vírus. O resultado dessa quebra é uma perda de função desses dois genes, acompanhada de uma desregulação dos genes E6 e $E 7$, resultando em transformação da célula hospedeira. A região do cromossomo ao qual o genoma viral se integra não parece 
Tabela 1

Descrição das funções dos genes do papiloma vírus humano.

\begin{tabular}{|c|c|}
\hline Gene & Função \\
\hline E1 & $\begin{array}{l}\text { Atividade de DNA helicase, ligação de ATP DNA dependente, atividade de ATPase. Papel na replicação e na } \\
\text { repressão da replicação. }\end{array}$ \\
\hline E2 & $\begin{array}{l}\text { Regulador da transcrição e replicação viral, controle da região de expressão precoce (Early), necessária para } \\
\text { replicação viral eficiente junto com E1. }\end{array}$ \\
\hline E3 & Sem função conhecida (presente apenas em uma minoria de papiloma vírus). \\
\hline E4 & $\begin{array}{l}\text { Expresso primariamente em epitélio em diferenciação, associado ao citoesqueleto de queratina de células } \\
\text { epiteliais em cultura. Papel na liberação de vírus. }\end{array}$ \\
\hline E5 & $\begin{array}{l}\text { Atividade de transformação em HPV16 in vitro. Possivelmente estimula o início da proliferação celular in vivo, } \\
\text { mas pode ter um papel na iniciação da carcinogênese. }\end{array}$ \\
\hline E6 & $\begin{array}{l}\text { Papel no processo de transformação junto com } E 7 \text {. Propriedades de ativação transcripcional. } E 6 \text { dos HPVs de alto } \\
\text { risco inativa } p 53 \text { através de degradação rápida através da via da ubiquitina. } 18 \text { Junto com } E 7 \text { propicia um } \\
\text { ambiente celular para a replicação viral. }\end{array}$ \\
\hline E7 & $\begin{array}{l}\text { Induz síntese de DNA em células em repouso. E7 se liga à forma hipo-fosforilada da proteína do retinoblastoma } \\
(p R b) \text {, resultando em sua inativação funcional permitindo progressão funcional para a fase } S \text { do ciclo celular. } \\
\text { Proteína } E 7 \text { dos tipos de baixo risco HPVs } 6 \text { e } 11 \text { se liga menos eficientemente do que a proteína } E 7 \text { dos tipo de } \\
\text { alto risco HPVs } 16 \text { e } 18 .\end{array}$ \\
\hline E8 & Sem função conhecida (presente apenas em uma minoria dos papilomas vírus). \\
\hline L1 & Proteína maior do capsídio (expressão tardia, Late). \\
\hline L2 & Proteína menor do capsídio. \\
\hline
\end{tabular}

Fonte: Sanclemente \& Gill.9

ser essencial para o desenvolvimento carcinogênico, uma vez que estas regiões variam muito.

Das proteínas codificadas pelo genoma do HPV, principalmente as produzidas pela expressão dos genes E6 e E7 estão relacionadas com a carcinogênese mediada pelo HPV. Contudo, o mecanismo exato pelo qual o produto desses genes age ainda não foi completamente esclarecido. É possível que a ação ocorra através de interação com proteínas reguladoras do ciclo celular. Em particular, foi demonstrado que E6 interage com a proteína $p 53$ e $E 7$ com a proteína $p R b$, causando desregulação do ciclo celular. ${ }^{18}$ Essas duas proteínas atuam prevenindo a transformação celular, interrompendo sua divisão e proliferação ${ }^{15,19}$ (Tabela 1).

As diferenças entre células normais e neoplásicas podem ser sutis, mas existem. As características únicas destas células as tornam excelentes alvos para a intervenção. O desenvolvimento de terapêuticas anti-carcinogênicas ainda é incipiente. Em breve, serão utilizados delineamentos racionais e acurados de biologia molecular e terapêutica gênica como adjuvantes no tratamento do câncer cervical e outros.

\section{Considerações finais}

A integração do DNA viral ao genoma da célula hospedeira é, provavelmente, o passo mais importante na carcinogênese cervical. A combinação da perda da regulação transcripcional viral e a ativação da transcrição do DNA viral integrado podem levar a super expressão de genes, que são essenciais ao desenvolvimento do carcinoma cervical. Alternativamente, a integração do DNA do HPV pode estar associada ou a um proto-oncogene ou a um gene supressor de tumor. O efeito dessa associação poderia levar a progressão de um fenótipo maligno.

O conhecimento dos mecanismos que estão envolvidos na oncogênese cervical tem sido possível devido à utilização de técnicas avançadas de biologia molecular. Algumas dessas técnicas permitem identificar grupos de HPV de alto ou baixo risco (captura híbrida) ou identificação de tipos virais específicos (Polymerase Chain Reaction PCR). ${ }^{20}$ São técnicas de fácil utilização, em laboratórios devidamente equipados, mas ainda com custo elevado. A associação dessas técnicas aos métodos diagnósticos clássicos, poderão levar a uma 
melhor avaliação das neoplasias cervicais e auxiliar no desenvolvimento de novas terapias, talvez menos invasivas e mais efetivas, como o uso de vacinas. Em breve, serão utilizados delineamentos racionais e acurados de biologia molecular e terapêutica gênica, como adjuvantes no tratamento do câncer cervical e outros.

A educação para saúde do público em geral através de campanhas de esclarecimento e adesão aos programas de acompanhamento e prevenção, associadas a eficácia destes métodos diagnósticos

\section{Referências}

1. Mao C, Hughes JP, Kiviat N, Kuypers J, Lee SK, Adam DE, et al. Clinical findings among young women with genital human papillomavirus infection. Am J Obstet Gynecol 2003; 188: 677-84.

2. Cronje HS. Screening for cervical cancer in developing countries. Int J Gynaecol Obstet 2004; 84: 101-8.

3. Alberts B, Bray D, Lewis J, Raff M, Roberts K, Watson JD. Molecular biology of the cell. 3 ed. Nova Iorque: Garland Publishing; 1994.

4. Rivoire WA, Capp E, Corleta VE, Brum I. Bases biomoleculares da oncogênese cervical. Rev Bras Cancerol 2001; 47: 179-84.

5. Brenna SM, Syrjanen KJ. Regulation of cell cycles is of key importance in human papillomavirus (HPV)-associated cervical carcinogenesis. São Paulo Med J 2003; 121: 12832.

6. Weinberg RA. How cancer arises. Sci Am 1996; 275: 6270.

7. Chen YC, Hunter DJ. Molecular epidemiology of cancer. CA Cancer J Clin 2005; 55: 45-54; quiz 57.

8. Stanley MA. Human papillomavirus and cervical carcinogenesis. Best Pract Res Clin Obstet Gynaecol 2001; 15 : 663-76.

9. Sanclemente G, Gill DK. Human papillomavirus molecular biology and pathogenesis. J Eur Acad Dermatol Venereol 2002; 16: 231-40

10. Von Knebel Doeberitz M. New markers for cervical dysplasia to visualise the genomic chaos created by aberrant oncogenic papillomavirus infections. Eur J Cancer 2002; 38: 2229-42. são as chaves para o sucesso de novas estratégias para combater o câncer cervical. No Brasil, como de resto, nos países emergentes, só se faz prevenção oportunística, que, infelizmente, não altera a curva de mortalidade. Cabe aos governos desses países, como do nosso, promover programas permanentes de rastreamento populacional. O câncer de colo uterino deixou de ser um problema médico, na medida em que a ciência propicia todos os meios para sua prevenção. Sua solução depende de meios econômicos e vontade política.
11. Scheurer ME, Tortolero-Luna G, Adler-Storthz K. Human papillomavirus infection: biology, epidemiology, and prevention. Int J Gynecol Cancer 2005; 15: 727-46.

12. Arends MJ, Buckley CH, Wells M. Aetiology, pathogenesis, and pathology of cervical neoplasia. J Clin Pathol 1998; 51: 96-103.

13. Schiffman M, Kjaer SK. Natural history of anogenital human papillomavirus infection and neoplasia. J Natl Cancer Inst Monogr 2003: 14-9.

14. Stubenrauch F, Laimins LA. Human papillomavirus life cycle: active and latent phases. Semin Cancer Biol 1999; 9: 379-86.

15. Beutner KR, Tyring S. Human papillomavirus and human disease. Am J Med 1997; 102: 9-15.

16. Kaufman RH, Adam E, Vonka V. Human papillomavirus infection and cervical carcinoma. Clin Obstet Gynecol 2000; 43: 363-80.

17. Burd EM. Human papillomavirus and cervical cancer. Clin Microbiol Rev 2003; 16: 1-17.

18. Kelley ML, Keiger KE, Lee CJ, Huibregtse JM. The global transcriptional effects of the human papillomavirus E6 protein in cervical carcinoma cell lines are mediated by the E6AP ubiquitin ligase. J Virol 2005; 79: 3737-47.

19. Pinto AP, Tulio S, Cruz OR. Hpv cofactors in cervical carcinogenesis. Rev Assoc Med Bras 2002; 48: 73-8.

20. Iftner T, Villa LL. Human papillomavirus technologies. J Natl Cancer Inst Monogr 2003: 80-8.

Recebido em 05 de maio de 2005.

Versão final apresentada em 16 de fevereiro de 2006

Aprovado em 1 de março de 2006 